\title{
An evaluation of commercial radioisotope methods for the determination of folate and vitamin $B_{12}$
}

\author{
DW DAWSON ${ }^{1}$, IW DELAMORE ${ }^{2}$, DI FISH ${ }^{1}$, TA FLAHERTY ${ }^{2}$, \\ AH GOWENLOCK ${ }^{3}$, LINDA P HUNT ${ }^{4}, \mathrm{~K}_{\mathrm{HYDE}}{ }^{2}$, JE MACIVER ${ }^{2}$, JANET A \\ THORNTON ${ }^{2}$, AND HM WATERS ${ }^{2}$
}

From the ${ }^{1}$ Department of Haematology, North Manchester General Hospital, ${ }^{2}$ Department of Haematology, Manchester Royal Infirmary, ${ }^{3}$ Department of Biochemistry, Manchester Royal Infirmary, and ${ }^{4}$ Faculty of Medicine, Computational Group, University of Manchester, UK

SUMMARY Five commercial kits for the determination of folate and six kits for the determination of vitamin $\mathrm{B}_{12}$ were investigated. Their performance has been compared with microbiological methods for the two vitamins and with a non-commercial radioisotopic method for $\mathrm{B}_{12}$. The results show the importance of the determination of the reference range for an individual laboratory for each method. The precision of the kits varied appreciably, as did their performance using specimens from patients with different haematological disorders. In particular, certain kits failed to detect all patients with pernicious anaemia. The relative accuracy of the kits was assessed. Various factors which should be taken into account in the final selection of a satisfactory kit are discussed.

In recent years, several commercial firms have introduced isotopic systems for the assay of folate and vitamin $B_{12}$. Their apparent ease of use has led to an increasing number of laboratories turning to them before their merits and demerits have been fully determined. At the end of 1977 the Laboratory and Development Advisory Group of the Department of Health and Social Security asked us to assess the kits available in the United Kingdom. Our full report was submitted in May 1979 to the Group. This paper lists the kits tested and summarises the procedures used and the findings obtained.

\section{Material and methods}

COMMERCIAL KITS

The kits investigated and their abbreviations are listed in Table 1.

NON-COMMERCIAL B12 RADIOASSAY METHOD ( $\mathrm{NCM}$ )

The NCM for $\mathrm{B}_{12}$ was that of Matthews et al. ${ }^{1}$

MICROBIOLOGICAL METHODS (MM)

The microbiological method used for the assay of folate was that of Davis et al. ${ }^{2}$

Received for publication 24 September 1979
Samples were also assayed for vitamin $\mathbf{B}_{12}$ using Lactobacillus leichmanii.

CONTROL MATERIALS

These consisted of Ortho RIA control sera I and II; pteroylglutamic acid (PGA) and N-5 methyl tetrahydrofolic acid (methyl THF) from Sigma London Chemical Co; Cyanocobalamin Injection BP of certified potency obtained from Glaxo Laboratories Ltd; 10 human serum pools of varying vitamin concentration and for $\mathrm{AM} \mathrm{B}_{12}$ the control samples provided with this kit.

REFERENCE AND CLINICAL SAMPLES

Reference samples were collected from 80 members of the hospital staff with an approximately equal sex distribution and a Gaussian age distribution. Thirteen donors on oral contraceptives were included. Clinical samples were taken from 70 patients for folate and from 80 other patients for $\mathrm{B}_{12}$ assays; in addition, a further 24 samples from patients suffering from pernicious anaemia were subsequently analysed.

ANALYTICAL ASSESSMENT

Linearity experiments for folate methods were conducted with pooled sera diluted in plasma protein fraction (PPF) and for $\mathrm{B}_{12}$ with dilutions of sera of high $B_{12}$ content in sera of low content. 
Table 1 Commercial kits investigated

\begin{tabular}{|c|c|c|c|c|}
\hline \multirow[t]{2}{*}{ Manufacturer } & \multicolumn{2}{|l|}{ Folate } & \multicolumn{2}{|l|}{$B_{12}$} \\
\hline & Abbreviation & Kit name & Abbreviation & Kit name \\
\hline $\begin{array}{l}\text { Becton Dickinson Immunodiagnostics } \\
\text { Biorad Laboratories } \\
\text { Radiochemical Centre (Amersham) } \\
\text { Pharmacia Diagnostics }\end{array}$ & $\begin{array}{l}\text { SIM } \\
\text { BD } \\
\text { QM } \\
\text { QCT } \\
\text { AM }\end{array}$ & $\begin{array}{l}\text { Simultrac Radioassay } \\
\text { Folate Radioassay } \\
\text { Quanta-mate } B_{12} / \text { Folate } \\
\text { Quanta-count Folate } \\
\text { Folate kit }\end{array}$ & $\begin{array}{l}\text { SIM } \\
\text { BD } \\
\text { QM } \\
\text { QCT } \\
\text { AM } \\
\text { PH }\end{array}$ & $\begin{array}{l}\text { Simultrac Radioassay* } \\
\mathbf{B}_{12} \text { Radioassay } \\
\text { Quanta-mate } \mathbf{B}_{12} / \text { Folate* } \\
\text { Quanta-count } \mathbf{B}_{12} \\
\mathbf{B}_{12} \text { kit } \\
\text { Phadebas } \mathbf{B}_{12} \text { test }\end{array}$ \\
\hline
\end{tabular}

*These kits determine folate and $B_{12}$ simultaneously.

Within-batch precision was based on the duplicates of the reference population. Between-batch precision was based on the variation between the means of the duplicates of serum samples assayed weekly throughout the duration of the trial. Accuracy was assessed from the results obtained for aqueous analyte assays, recovery of added vitamin, and correlation with the comparative methods. Shelf-life was studied by comparing pairs of results from assays done with kits at the beginning and at a later stage in their stated shelf-life. Reconstituted reagents were tested similarly after storage according to the manufacturer's recommendations.

\section{ASSAY COMPOSITION}

The assays were performed using three different batches of each kit. All samples were tested in duplicate except for the folate microbiological methods which had to be done singly because of a national shortage of assay medium at the time of the trial.

\section{CLINICAL EVALUATION}

This was based on the following:

(A) The likelihood of vitamin deficiency was assessed in each patient from the history and clinical and laboratory findings, but without knowledge of the assay results of the vitamin under investigation. Patients were allocated to one of the following three groups: deficiency, 1-probable; 2-possible; 3 -unlikely. The mean and standard deviation for the results in each group were compared to assess the ability of each kit to distinguish between the groups. (B) Because of the difference between kits in assay ranges for the reference population, the individual results for each kit were converted to log-standardised scores* to permit direct comparison between methods and to identify those results that were

*This score is the number of SDs above $(+)$ or below $(-)$ the mean, by that method, of the reference population after logarithmic transformation of all results. discrepant both with the clinical grouping and with the majority of all the results. Discrepancies of possible clinical importance were a normal result in group 1 (major error), an inappropriately low or normal result in group 2, and a low result in group 3. Other discrepancies of doubtful significance, for example, a normal when a high result was expected, were also noted.

(C) Results in diseases of particular significance were separately analysed.

\section{SUBJECTIVE ASSESSMENT AND COSTING}

This took into account compliance with arranged delivery dates, kit packaging, clarity and detail of instructions provided, ease of use of the kit, reagent adequacy, the number and reason for failures, and a comparative cost analysis, which excluded capital and other fixed costs.

\section{Results}

\section{DETERMINATION OF $95 \%$ REFERENCE RANGES}

Frequency distribution analysis showed that the results, although unimodal, were positively skewed, and hence a logarithmic (base 10) transformation was applied in an attempt to normalise the distribution. Non-parametric statistical tests were used for investigation of non-transformed folate/ $\mathbf{B}_{12}$ results. Table 2 shows the $95 \%$ reference ranges, using the parametric method, based on the means of replicates after logarithmic transformation.

\section{ANALYTICAL ASSESSMENT}

\section{Linearity}

In all cases the relationship was compatible with a linear one although, in some, the error attached to certain calibration points was high.

\section{Precision}

Within-batch precision results for the reference population samples are shown in Table 3. The 
Table 2 Reference ranges

\begin{tabular}{|c|c|c|c|c|c|c|c|}
\hline \multirow[t]{2}{*}{ Method } & & \multicolumn{3}{|l|}{ Folate $(\mu \mathrm{g} / \mathrm{l})$} & \multicolumn{3}{|l|}{$B_{12}(n g / l)$} \\
\hline & & $95 \%$ confidence limits & $n$ & Manufacturer's* range & $95 \%$ confidence limits & $n$ & Manufacturer's range \\
\hline SIM & $\begin{array}{l}\text { Serum } \\
\text { RBC }\end{array}$ & $\begin{array}{l}1 \cdot 7-14 \cdot 3 \\
101-749\end{array}$ & $\begin{array}{l}61 \\
44\end{array}$ & $\begin{array}{l}4 \cdot 0-20 \cdot 0 \\
200-800\end{array}$ & $251-974$ & 75 & $200-900$ \\
\hline QM & $\begin{array}{l}\text { Serum } \\
\text { RBC }\end{array}$ & $\begin{array}{l}1 \cdot 6-10 \cdot 6 \\
98-755\end{array}$ & $\begin{array}{l}72 \\
70\end{array}$ & $\begin{array}{l}>3 \cdot 0 \\
\text { Not stated }\end{array}$ & $277-958$ & 76 & $310-1100$ \\
\hline QCT & $\begin{array}{l}\text { Serum } \\
\text { RBC }\end{array}$ & $\begin{array}{l}2 \cdot 7-10 \cdot 5 \\
126-614\end{array}$ & $\begin{array}{l}76 \\
66\end{array}$ & $\begin{array}{l}1 \cdot 9-14 \cdot 0 \\
120-674\end{array}$ & $385-1062$ & 72 & $200-1100$ \\
\hline BD & $\begin{array}{l}\text { Serum } \\
\text { RBC }\end{array}$ & $\begin{array}{l}1 \cdot 4-8 \cdot 5 \\
60-401\end{array}$ & $\begin{array}{l}65 \\
58\end{array}$ & $\begin{array}{l}4 \cdot 0-20 \cdot 0 \\
200-800\end{array}$ & $334-956$ & 76 & $200-900$ \\
\hline $\mathbf{A M}$ & $\begin{array}{l}\text { Serum } \\
\text { RBC }\end{array}$ & $\begin{array}{l}1 \cdot 9-13 \cdot 6 \\
113-820\end{array}$ & $\begin{array}{l}65 \\
68\end{array}$ & $\begin{array}{l}>4.0 \\
>200\end{array}$ & $205-792$ & 76 & $200-1000$ \\
\hline PH & Serum & & & & $310-1170$ & 71 & $300-1000$ \\
\hline MM & $\begin{array}{l}\text { Serum } \\
\text { RBC }\end{array}$ & $\begin{array}{l}2 \cdot 2-11 \cdot 7 \\
120-478\end{array}$ & $\begin{array}{l}75 \\
71\end{array}$ & $\begin{array}{l}3 \cdot 0-8 \cdot 0 \\
>150\end{array}$ & $114-1112$ & 69 & $150-1000$ \\
\hline NCM & Serum & & & & 139-585 & 75 & $120-900$ \\
\hline
\end{tabular}

*The terms and conditions under which the manufacturers' 'normal' ranges have been determined vary widely (see individual kit protocols for details).

Table 3 Average within-batch precision results for the reference population

\begin{tabular}{|c|c|c|c|c|c|c|c|}
\hline \multirow[t]{2}{*}{ Method } & & \multicolumn{3}{|l|}{ Folate } & \multicolumn{3}{|l|}{$B_{12}$} \\
\hline & & $C V \%$ & $S D(\mu g / l)$ & $n$ & $\mathrm{CV} \%$ & $S D(n g \mid l)$ & $n$ \\
\hline SIM & $\begin{array}{l}\text { Serum } \\
\text { RBC }\end{array}$ & $\begin{array}{l}20 \cdot 5 \\
14 \cdot 1\end{array}$ & $\begin{array}{l}19 \cdot 1 \\
16.0\end{array}$ & $\begin{array}{l}58 \\
43\end{array}$ & $10 \cdot 1$ & 8.9 & 75 \\
\hline $\mathbf{Q M}$ & $\begin{array}{l}\text { Serum } \\
\text { RBC }\end{array}$ & $\begin{array}{l}5.5 \\
5.8\end{array}$ & $\begin{array}{l}6.6 \\
5.9\end{array}$ & $\begin{array}{l}72 \\
70\end{array}$ & $6 \cdot 5$ & $6 \cdot 3$ & 76 \\
\hline QCT & $\begin{array}{l}\text { Serum } \\
\text { RBC }\end{array}$ & $\begin{array}{l}4 \cdot 5 \\
5 \cdot 7\end{array}$ & $\begin{array}{l}4 \cdot 3 \\
6 \cdot 1\end{array}$ & $\begin{array}{l}76 \\
66\end{array}$ & $4 \cdot 6$ & $4 \cdot 8$ & 72 \\
\hline BD & $\begin{array}{l}\text { Serum } \\
\text { RBC }\end{array}$ & $\begin{array}{l}7.7 \\
7.5\end{array}$ & $\begin{array}{l}7.0 \\
7.6\end{array}$ & $\begin{array}{l}65 \\
58\end{array}$ & $3 \cdot 4$ & $3 \cdot 3$ & 76 \\
\hline $\mathbf{A M}$ & $\begin{array}{l}\text { Serum } \\
\text { RBC }\end{array}$ & $\begin{array}{l}18 \cdot 4 \\
13 \cdot 7\end{array}$ & $\begin{array}{l}15 \cdot 3 \\
15 \cdot 9\end{array}$ & $\begin{array}{l}61 \\
68\end{array}$ & 3.9 & $3 \cdot 6$ & 76 \\
\hline $\begin{array}{l}\text { PH } \\
\text { MM } \\
\text { NCM }\end{array}$ & $\begin{array}{l}\text { Serum } \\
\text { Serum } \\
\text { Serum }\end{array}$ & & & & $\begin{array}{r}6 \cdot 6 \\
14 \cdot 6 \\
6 \cdot 4\end{array}$ & $\begin{array}{r}7 \cdot 3 \\
10 \cdot 9 \\
5 \cdot 1\end{array}$ & $\begin{array}{l}67 \\
61 \\
75\end{array}$ \\
\hline
\end{tabular}

$\mathbf{n}=$ number of pairs. The high CV\% with SIM and AM for folate may have been due, in part, to technical difficulties.

variation of between-batch precision with concentration is demonstrated in Figures 1 and 2.

Accuracy

Assay of pure analyte yielded variable results (Table 4), and recovery of both vitamins was disappointing (Table 5). Correlation between methods is illustrated in Table 6 , which summarises regression analysis for all methods and is derived from $\log$ scores for reference and clinical samples combined.

\section{Shelf-life and stability of reconstituted reagents}

All folate kits tested had a six-week shelf-life and, with the exception of SIM, which showed a fall of $0.75 \mu \mathrm{g} / 1$, no significant differences were found between the beginning and end of the six-week period. The $B_{12}$ kits tested had shelf-lives of varying lengths, and different time periods were tested. Due to shortage of assay material, no result for $\mathbf{P H}$ shelf-life was available. For QCT and AM no

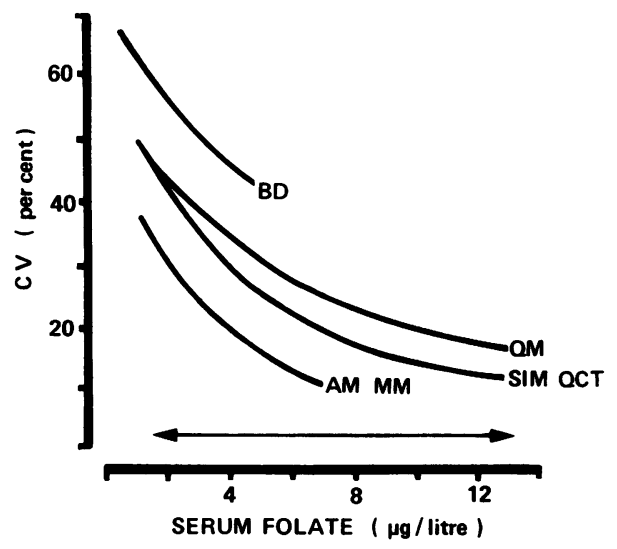

Fig. 1 Variation of between-batch precision of serum folate with concentration.

significant differences were found, while statistically significant differences were demonstrated for SIM, 




Fig. 2 Variation of between-batch precision of serum $B_{12}$ with concentration.

$\mathrm{QM}$, and BD. The mean results with each showed a fall of about $100 \mathrm{ng} / \mathrm{l}$.

Significant differences were demonstrated at various stages when reagents were stored after reconstitution. For folate, significant differences were found with QCT, BD, and AM, in all cases lower mean results $(0 \cdot 6,1 \cdot 5$, and $0 \cdot 4 \mu \mathrm{g} / \mathrm{l}$ less, respectively) being obtained on the second assay. When significant differences were found, they were not present in both batches, suggesting different storage characteristics between batches. For $\mathrm{B}_{12}$, both batches were affected for SIM, AM, and PH but only one batch for BD. The maximum change was $140 \mathrm{ng} / \mathrm{l}$. Both batches of QCT were apparently stable, but only one batch of QM was tested.

CLINICAL EVALUATION

All kits, with one exception (SIM for RBC assay), were able to distinguish possible from probable deficiency of folate and vitamin $B_{12}$. The numbers of discrepancies are shown in Tables 7 and 8.

\section{DISEASE GROUPS}

\section{Folate assays (Table 9)}

Megaloblastic anaemia due to folate deficiency $(9$ patients) All results were abnormally low except for two by BD and AM and one by MM. For RBC assay by: SIM 1 of 4, QM 0 of 9, QCT 0 of 8, BD 1 of 6 , AM 2 of 9 , and MM 1 of 9 were normal.

$P A$ (11 patients) The mean serum score was normal

Table 4 Assay of pure analyte

\begin{tabular}{|c|c|c|c|}
\hline \multirow[t]{2}{*}{ Method } & \multicolumn{2}{|l|}{ Folate } & \multirow{2}{*}{$\frac{B_{12}}{\text { Cyanocobalamin }(100 \mathrm{ng} / \mathrm{l})}$} \\
\hline & $P G A(5 \mu g / l)$ & Methyl THF $(5 \mu g / l)$ & \\
\hline $\begin{array}{l}\text { SIM } \\
\text { QM } \\
\text { QCT } \\
\text { BD }\end{array}$ & $\begin{array}{r}15 \cdot 9 \pm 2 \cdot 2(16) \\
9 \cdot 4 \pm 1 \cdot 9(18) \\
8 \cdot 5 \pm 1 \cdot 9(20) \\
12 \cdot 6 \pm 3 \cdot 8(13)\end{array}$ & $\begin{array}{l}17 \cdot 7 \pm 2 \cdot 2(16) \\
18 \cdot 2 \pm 2 \cdot 0(18) \\
16 \cdot 8 \pm 2 \cdot 0(20) \\
15 \cdot 2 \pm 3 \cdot \%(14)\end{array}$ & $\begin{array}{l}163 \pm 23(22) \\
159 \pm 13(20) \\
1628 \pm 118(16) \\
>2000 \\
\text { (Background counts only obtaired) }\end{array}$ \\
\hline $\begin{array}{l}\text { AM } \\
\text { PH } \\
\text { MM } \\
\text { NCM }\end{array}$ & $\begin{array}{l}5 \cdot 3 \pm 2 \cdot 6(16) \\
4 \cdot 9 \pm 0 \cdot 3(10)\end{array}$ & $\begin{array}{r}7 \cdot 1 \pm 4 \cdot 5(16) \\
12 \cdot 3 \pm 5 \cdot 2(10)\end{array}$ & $\begin{array}{r}279 \pm 59(22) \\
104 \pm 6(22) \\
90 \pm 10(22)\end{array}$ \\
\hline
\end{tabular}

Results are mean $\pm 2 \mathrm{SE}$; number of observations in brackets.

Table 5 Recovery experiments

\begin{tabular}{|c|c|c|c|c|}
\hline \multirow[t]{2}{*}{ Method } & \multicolumn{2}{|c|}{ Folate $\%$ recovery } & \multicolumn{2}{|l|}{$B_{12} \%$ recovery } \\
\hline & $P G A$ & Methyl THF & Cyanocobalamin $(100 \mathrm{ng} / \mathrm{l})$ & Cyanocobalamin $(400 \mathrm{ng} / \mathrm{l})$ \\
\hline $\begin{array}{l}\text { SIM } \\
\text { QM } \\
\text { QCT } \\
\text { BD } \\
\text { AM } \\
\text { PH } \\
\text { MM } \\
\text { NCM }\end{array}$ & $\begin{array}{l}73 \pm 10(35) \\
86 \pm 7(32) \\
77 \pm 7(36) \\
84 \pm 13(26) \\
57 \pm 13(18) \\
73 \pm 10(18)\end{array}$ & $\begin{array}{l}38 \pm 7(34) \\
72 \pm 4(31) \\
63 \pm 5(36) \\
36 \pm 5(27) \\
54 \pm 11(22) \\
24 \pm 7(21)\end{array}$ & $\begin{array}{r}104 \pm 77(8) \\
86 \pm 43(9) \\
73 \pm 29(9) \\
87 \pm 23(9) \\
82 \pm 19(9) \\
73 \pm 27(9) \\
74 \pm 31(7)\end{array}$ & $\begin{array}{r}101 \pm 12(8) \\
91 \pm 19(9) \\
91 \pm 14(8) \\
102 \pm 11(9) \\
87 \pm 5(9) \\
94 \pm 18(8) \\
63 \pm 13(8)\end{array}$ \\
\hline
\end{tabular}

Results are mean $\pm 2 \mathrm{SE}$; number of observations in brackets.

For $B_{12}$ only the wide variation in results obtained made them appear to give figures compatible with $100 \%$ recovery. However, AM and NCM were incompatible with the complete recovery of $400 \mathrm{ng} / \mathrm{l}$. 
Table 6 Folate $/ B_{12}$ regression analysis

\begin{tabular}{|c|c|c|c|c|c|c|}
\hline \multirow[t]{2}{*}{ Sample type } & \multicolumn{2}{|l|}{ Method } & \multirow[t]{2}{*}{$r$} & \multirow[t]{2}{*}{ Slope } & \multirow[t]{2}{*}{ Intercept } & \multirow[t]{2}{*}{$n$} \\
\hline & $X$-axis & $Y$-axis & & & & \\
\hline Serum folate & $\begin{array}{l}\text { MM } \\
\text { MM } \\
\text { MM } \\
\text { MM } \\
\text { MM }\end{array}$ & $\begin{array}{l}\text { SIM } \\
\text { QM } \\
\text { QCT } \\
\text { BD } \\
\text { AM }\end{array}$ & $\begin{array}{l}0.71 \\
0.89 \\
0.90 \\
0.74 \\
0.76\end{array}$ & $\begin{array}{l}0.58 \\
0.92 \\
1.08 \\
0.54 \\
0.52\end{array}$ & $\begin{array}{l}-0.44 \\
-0.22 \\
-0.36 \\
-0.06 \\
-0.02\end{array}$ & $\begin{array}{l}121 \\
136 \\
143 \\
122 \\
126\end{array}$ \\
\hline $\mathbf{R B C}$ folate & $\begin{array}{l}\text { MM } \\
\text { MM } \\
\text { MM } \\
\text { MM } \\
\text { MM }\end{array}$ & $\begin{array}{l}\text { SIM } \\
\text { QM } \\
\text { QCT } \\
\text { BD } \\
\text { AM }\end{array}$ & $\begin{array}{l}0.59 \\
0.80 \\
0.86 \\
0.74 \\
0.65\end{array}$ & $\begin{array}{l}0.90 \\
0.85 \\
1.46 \\
1.01 \\
0.59\end{array}$ & $\begin{array}{r}-0.24 \\
0.08 \\
-0.08 \\
-0.10 \\
-0.06\end{array}$ & $\begin{array}{r}97 \\
137 \\
125 \\
106 \\
134\end{array}$ \\
\hline Serum $\mathbf{B}_{12}$ & $\begin{array}{l}\mathrm{NCM} \\
\mathrm{NCM} \\
\mathrm{NCM} \\
\mathrm{NCM} \\
\mathrm{NCM} \\
\mathrm{NCM} \\
\mathrm{NCM}\end{array}$ & $\begin{array}{l}\text { SIM } \\
\text { QM } \\
\text { QCT } \\
\text { BD } \\
\text { AM } \\
\text { PH } \\
\text { MM }\end{array}$ & $\begin{array}{l}0.87 \\
0.91 \\
0.88 \\
0.83 \\
0.79 \\
0.82 \\
0.86\end{array}$ & $\begin{array}{l}0.83 \\
0.81 \\
0.89 \\
0.83 \\
0.72 \\
0.78 \\
0.63\end{array}$ & $\begin{array}{l}0.25 \\
0.12 \\
0.12 \\
0.33 \\
0.34 \\
0.11 \\
0.09\end{array}$ & $\begin{array}{l}154 \\
146 \\
150 \\
155 \\
155 \\
155 \\
141\end{array}$ \\
\hline Serum $\mathbf{B}_{12}$ & $\begin{array}{l}\text { MM } \\
\text { MM } \\
\text { MM } \\
\text { MM } \\
\text { MM } \\
\text { MM } \\
\text { MM }\end{array}$ & $\begin{array}{l}\text { SIM } \\
\text { QM } \\
\text { QCT } \\
\text { BD } \\
\text { AM } \\
\text { PH } \\
\text { NCM }\end{array}$ & $\begin{array}{l}0.88 \\
0.90 \\
0.91 \\
0.88 \\
0.83 \\
0.86 \\
0.86\end{array}$ & $\begin{array}{l}1 \cdot 16 \\
1 \cdot 12 \\
1 \cdot 29 \\
1 \cdot 24 \\
1 \cdot 05 \\
1 \cdot 13 \\
1 \cdot 18\end{array}$ & $\begin{array}{r}0.15 \\
-0.01 \\
-0.06 \\
0.20 \\
0.26 \\
0.02 \\
-0.26\end{array}$ & $\begin{array}{l}142 \\
133 \\
138 \\
142 \\
142 \\
142 \\
141\end{array}$ \\
\hline
\end{tabular}

$\mathbf{r}=$ correlation coefficient.

$\mathbf{n}=$ number of pairs.

Table 7 Folate: frequency of discrepancies in clinical groups

\begin{tabular}{|c|c|c|c|c|c|c|}
\hline Sample type & Method & Group 1 & Group 2 & Group 3 & Other & Total \\
\hline Serum & $\begin{array}{l}\text { SIM } \\
\text { QM } \\
\text { QCT } \\
\text { BD } \\
\text { AM } \\
\text { MM }\end{array}$ & $\begin{array}{l}1 / 13 \\
0 / 14 \\
0 / 15 \\
4 / 13 \\
3 / 14 \\
1 / 17\end{array}$ & $\begin{array}{l}3 / 16 \\
0 / 16 \\
0 / 16 \\
1 / 13 \\
1 / 16 \\
1 / 16\end{array}$ & $\begin{array}{l}0 / 34 \\
0 / 36 \\
2 / 38 \\
2 / 33 \\
1 / 33 \\
1 / 38\end{array}$ & $\begin{array}{l}5 \\
0 \\
0 \\
4 \\
2 \\
2\end{array}$ & $\begin{array}{r}9 \\
0 \\
2 \\
11 \\
7 \\
5\end{array}$ \\
\hline $\mathbf{R B C}$ & $\begin{array}{l}\text { SIM } \\
\text { QM } \\
\text { QCT } \\
\text { BD } \\
\text { AM } \\
\text { MM }\end{array}$ & $\begin{array}{l}3 / 10 \\
0 / 15 \\
0 / 13 \\
2 / 10 \\
3 / 14 \\
1 / 17\end{array}$ & $\begin{array}{l}0 / 13 \\
2 / 15 \\
2 / 12 \\
0 / 10 \\
0 / 15 \\
0 / 16\end{array}$ & $\begin{array}{l}2 / 32 \\
1 / 37 \\
4 / 34 \\
2 / 29 \\
1 / 36 \\
1 / 38\end{array}$ & $\begin{array}{l}2 \\
8 \\
2 \\
1 \\
7 \\
0\end{array}$ & $\begin{array}{r}7 \\
11 \\
8 \\
5 \\
11 \\
2\end{array}$ \\
\hline
\end{tabular}

Table $8 \quad B_{12}$ : frequency of discrepancies in clinical groups

\begin{tabular}{llllll}
\hline Method & Group 1 & Group 2 & Group 3 & Other & Total \\
\hline SIM & $1 / 9$ & $2 / 30$ & $0 / 33$ & 1 & 4 \\
QM & $0 / 9$ & $2 / 27$ & $0 / 30$ & 4 & 6 \\
QCT & $0 / 9$ & $5 / 30$ & $0 / 32$ & 0 & 5 \\
BD & $1 / 9$ & $3 / 30$ & $0 / 33$ & 1 & 5 \\
AM & $1 / 9$ & $4 / 30$ & $0 / 33$ & 2 & 7 \\
PH & $0 / 9$ & $1 / 30$ & $0 / 33$ & 1 & 2 \\
NCM & $0 / 9$ & $7 / 30$ & $0 / 33$ & 7 & 14 \\
MM & $0 / 9$ & $3 / 30$ & $0 / 28$ & 0 & 3 \\
\hline
\end{tabular}

by all methods, and lowest by SIM. The mean RBC result was below normal by all except $\mathrm{AM}$ and very low by BD.
Patients on folic acid therapy (11 patients) The serum results were below normal in three, and it is considered that they were not taking the tablets. In the other eight, the results were above normal by $\mathbf{M M}$ in all, by QCT in seven, by QM in six, by $A M$ in five, by BD in four, and by SIM in three.

Iron deficiency ( 6 patients) There were some, but no consistent, discrepancies between MM and some kits, most commonly AM, and unexpectedly low results with QCT.

Vitamin $B_{12}$ assays (Table 10)

$P A$ With the original eight patients a low serum $B_{12}$ was recorded by all kits except in one sample by 
Table 9 Folate: mean log scores

\begin{tabular}{|c|c|c|c|c|c|}
\hline Method & & $\begin{array}{l}\text { Megaloblastic anaemia } \\
\text { due to folate deficiency }\end{array}$ & $P A$ & $\begin{array}{l}\text { Patients on folic } \\
\text { acid }\end{array}$ & $\begin{array}{l}\text { Patients with iron } \\
\text { deficiency }\end{array}$ \\
\hline SIM & $\begin{array}{l}\text { Serum } \\
\text { RBC }\end{array}$ & $\begin{array}{l}-4.34 \\
-4.48\end{array}$ & $\begin{array}{l}-1.21 \\
-4.54\end{array}$ & $\begin{array}{l}0.88 \\
1 \cdot 14\end{array}$ & $\begin{array}{l}-0.59 \\
-0.01\end{array}$ \\
\hline $\mathbf{Q M}$ & Serum & -6.04 & -0.53 & $\begin{array}{l}1.14 \\
1.69\end{array}$ & -0.46 \\
\hline & $\mathbf{R B C}$ & $-5 \cdot 10$ & $-2 \cdot 20$ & 0.79 & 0.68 \\
\hline QCT & Serum & $-7 \cdot 10$ & -0.95 & $1 \cdot 19$ & -1.90 \\
\hline & RBC & $-9 \cdot 22$ & $-4 \cdot 81$ & 0.65 & -0.42 \\
\hline BD & Serum & $-2 \cdot 83$ & 0.08 & 1.08 & -0.12 \\
\hline & RBC & -4.68 & -6.07 & 1.07 & 0.56 \\
\hline $\mathbf{A M}$ & Serum & $-2 \cdot 86$ & -0.02 & 1.45 & -1.06 \\
\hline & RBC & $-\mathbf{3} \cdot 97$ & -1.09 & -0.02 & -0.62 \\
\hline $\mathbf{M M}$ & Serum & -4.87 & -0.52 & 1.74 & -0.65 \\
\hline
\end{tabular}

Table $10 \quad B_{12}:$ mean log scores

\begin{tabular}{lcccc}
\hline Method & $P A^{*}$ & Folate deficiency & Iron deficiency & Myeloproliferative disease \\
\hline SIM & -5.04 & -1.24 & -1.46 & 4.64 \\
QM & -3.98 & -1.59 & -1.23 & 3.40 \\
QCT & -10.41 & -1.50 & -1.37 & 4.27 \\
BD & -4.68 & -1.21 & -1.11 & 5.08 \\
AM & -6.77 & -1.16 & -1.07 & 4.53 \\
PH & -5.02 & -1.58 & -1.57 & 3.26 \\
MM & -4.32 & -1.39 & -1.26 & 2.17 \\
NCM & -5.27 & -2.36 & -2.03 & 2.94 \\
\hline
\end{tabular}

*Includes additional 24 sera, except with MM.

Table 11 Subjective assessment and costing

\begin{tabular}{|c|c|c|c|c|c|c|c|}
\hline Kit & Analyte & Delivery & Packaging & $\begin{array}{l}\text { Protocol } \\
\text { comprehension }\end{array}$ & $\begin{array}{l}\text { Reagent } \\
\text { reconstitution }\end{array}$ & $\begin{array}{l}\text { Reagent } \\
\text { adequacy }\end{array}$ & $\begin{array}{l}\text { Total } \\
\text { cost/patient }(£)\end{array}$ \\
\hline SIM & Folate/B $\mathbf{B}_{12}$ & 3 & 4 & 5 & 3 & 2 & $1 \cdot 31$ \\
\hline $\mathbf{Q M}$ & Folate/B $/ \mathbf{B}_{12}$ & 3 & 4 & 4 & 4 & 4 & $\mathrm{j} \cdot 46$ \\
\hline QCT & Folate & 3 & 4 & 4 & 4 & 4 & 0.99 \\
\hline & $B_{12}$ & 3 & 4 & 4 & 4 & 4 & 1.08 \\
\hline BD & Folate & 3 & 4 & 5 & 3 & 2 & 0.93 \\
\hline & $\mathrm{B}_{12}$ & 3 & 4 & 5 & 4 & 2 & $1 \cdot 25$ \\
\hline $\mathbf{A M}$ & Folate & 3 & 4 & 4 & 5 & 4 & 1.09 \\
\hline & $B_{12}$ & 3 & 4 & 4 & 5 & 4 & 0.98 \\
\hline $\mathbf{P H}$ & $B_{12}$ & 4 & 4 & 2 & 2 & 3 & $0 \cdot 71$ \\
\hline
\end{tabular}

Various aspects were scored on a 1 (bad) to 5 (excellent) scale, in which 3 was taken as 'satisfactory'.

AM. Of the further 24 sera, three were normal by QM and two each by BD and AM. All were subnormal by SIM and QCT, which had been modified since the main trial, and by PH. Against the manufacturer's range 10 were normal by $\mathrm{BD}$ and one by QM.

Folate deficiency ( 7 patients) There was no overlap between the results in this group and pernicious anaemia with any kit except AM.

Iron deficiency ( 8 patients) The majority of results were below the mean of the reference ranges, and there was generally agreement between the kits.
Myeloproliferative disease (5 chronic myeloid leukaemia, 1 polycythaemia rubra vera) All results, except one by QM, were above the reference range.

SUBJECTIVE ASSESSMENT AND COSTING

The results are shown in Table 11.

\section{Kit failure}

Kit failure was defined as failure to show adequate trace binding, failure to produce a satisfactory curve, or failure to produce results. For folate, SIM failed to produce adequate trace binding on six occasions out of 12, and BD on one occasion out of 12. $\mathrm{QM}$ and $\mathbf{A M}$ each failed to produce a satis- 
factory standard curve on one occasion. AM failed to produce satisfactory results owing to protein precipitation with 11 of 76 sera. For $B_{12}$, two sera produced a protein gel with $\mathrm{PH}$, which prevented results being obtained.

\section{Discussion}

The selection of any analytical method requires consideration of several aspects, and it is not often that one particular method excels in all these so that the ultimate choice is a matter of judgement as to the relative importance of good and bad points.

In order to evaluate the clinical usefulness of a method it is essential to establish a reference range. The $95 \%$ reference ranges that we obtained varied considerably between methods, presumably reflecting differing accuracies. They also varied somewhat from those proposed by the manufacturers. Even with our criteria for selection, the residual apparently healthy population could still include cases of subclinical folate deficiency. With QCT and $\mathrm{BD}$, our ranges for $\mathrm{B}_{12}$ are rather higher, and for QM lower, than those of the manufacturers, suggesting that the reference population used is a reasonably typical one. These points emphasise the need to determine independent reference ranges. Throughout the evaluation, samples from the reference population and from the patients were assayed in parallel to allow direct comparison of results.

Our precision measurements were more comprehensive than those usually employed and are more likely to reflect the actual conditions in the laboratory for which the kits are intended. The precision attained by the majority of methods was worse than the CV of $10 \%$ usually achievable by radioisotope assays.

The within-batch precision of folate assays was disappointing at low levels, QM, QCT, and BD giving acceptable results, whereas, probably owing to technical difficulties encountered with their use, SIM and AM did not. The AM kit has been reported to give CVs from 4 to $17 \%$ and other ${ }^{125}$ I-labelled folate kits CVs from 1.6 to $13.8 \% \%^{5,6}$ The withinbatch precision for $\mathrm{B}_{12}$ assays was more satisfactory, all except SIM and MM giving acceptable results with the reference population. Our findings for $\mathbf{P H}$ were similar to the CV of $6.3 \%$ achieved by Raven and Robson.?

Between-batch precision for serum folate was less satisfactory than was hoped for. The CV was worse at the lower end of the normal range but fell with increasing concentration, although the whole range was covered for only SIM, QM, and QCT. The best performance at the lower end of the reference ranges was a $\mathrm{CV}$ of about $30 \%$ for $\mathrm{AM}$ and $\mathrm{MM}$, but extrapolation from the results suggests that this will fall below $10 \%$ at concentrations above $7 \mu \mathrm{g} / \mathrm{l}$. No other kit seems likely to achieve the figure of $10 \%$ at any concentration. Published data for folate kits from this same group of manufacturers have yielded somewhat lower between-batch CVs than ours, but these are based on small samples over shorter times; figures vary between 6.6 and $15 \%$ over the concentration range $3 \cdot 4-10 \mu \mathrm{g} / \mathrm{l}^{3,6,8}$ For $\mathrm{B}_{12}$ assays, between-batch precision was better than for folate and, in particular, the CVs for AM and QCT remained below $10 \%$ over the whole of the reference range. $\mathrm{PH}$ gave the next most consistent performance, and our figures are similar to those of Raven and Robson. ${ }^{7}$

When no independently validated reference material is available, as is the case with folate and $B_{12}$, accuracy of methods is difficult to study. The use of pure aqueous solutions to assess accuracy is not possible for most kits, presumably because assay conditions are not designed for such material. Another traditional approach is the recovery experiment, and once again the results are unhelpful. With all kits the recovery of PGA was low and of methyl THF lower. Most kits are not calibrated with methyl THF standards, and this could explain the poor recovery of this form of folate; however, AM is calibrated with methyl THF, and the recovery is still poor. The disappointing recoveries may have been due to loss dur:ng extraction, even when ascorbate is present. Kubasik et al. ${ }^{5}$ recorded very poor methylfolate recovery with two other ${ }^{125}$ I kits using PGA and methyl THF standards, while recovery apparently exceeded $500 \%$ when PGA was used with a third kit. With $\mathrm{B}_{12}$, the results appear more acceptable but variation was much greater than with folate. Again losses occur during extraction but the standards undergo the same processing except for $\mathrm{PH}$ and NCM where recoveries were the lowest. $\mathrm{B}_{12}$ added in vitro is bound mainly to transcobalamin II rather than $R$ binders and may thus behave differently from endogenous $B_{12}$ during extraction. The study of relative accuracy by linear regression analysis confirmed that the methods differ in accuracy but it is not possible to say which, if any, is accurate.

However precise a method may be, the clinical performance should ultimately determine whether it is suitable for routine use. A low serum folate is of limited value since it merely indicates a negative balance, although, in our experience, to be significant the result ought to be very low in the presence of tissue changes. In this respect two kits, QM and QCT, were the most satisfactory and better than the MM method. Because of the sensitivity of the serum level to folate imbalance, $\mathrm{RBC}$ assay is considered the 
better indicator of tissue deficiency. The same kits were also the best in this assay. The kits that gave the highest serum folate results in pernicious anaemia unfortunately also gave the highest results in folate deficiencies. AM and QCT were of appropriate sensitivity with the lowest results in folate deficiency and the greatest difference from those in pernicious anaemia. The results in patients on folic acid therapy were disappointing, no kits detecting the expected raised level. For RBC folate, QM and QCT were the most satisfactory. Whether only really important, or all, errors in folate assays are considered, QM and QCT were the most satisfactory, though no kit had as few errors as MM.

In $\mathrm{B}_{12}$ assays the outstanding necessity is for the method to yield a low level in pernicious anaemia. Since this work began there have been disconcerting reports ${ }^{9,10}$ of normal results with some kits, though earlier reports of radioisotope methods had not recorded a frequency of error of the same magnitude.1,11,12 The errors with three kits (AM, QM, and BD) were similar in incidence to those obtained by Cooper and Whitehead ${ }^{10}$ with BD and with their own method but less than the $20 \%$ anticipated by Kolhouse et al. ${ }^{9}$ With four sera the test was wrong with one kit only, indicating that the kit formulation as much as the presence of serum cobamides is responsible. This is supported by the consistent correctness of $\mathrm{PH}$ and the modified forms of SIM and QCT. It appears to be the presence of $R$ binder which leads to falsely normal cobalamin levels ${ }^{9}$ although several workers, $1,11,13$ and NCM (this report) using human serum as binder, have failed to show error in testing 77 pernicious anaemia sera. However, the patient's serum plays some part because, as noted by Cooper and Whitehead, ${ }^{10}$ false results are connected with less severe degrees of anaemia. Our six patients with an incorrect result had a mean haemoglobin of $11.0 \mathrm{~g} / \mathrm{dl}$ compared with $9.2 \mathrm{~g} / \mathrm{dl}$ in the others. In myeloproliferative disorders all kits gave higher $\mathbf{B}_{12}$ levels than $\mathbf{M M}$.

When the analytical and clinical performance are considered together it appears that, of the various kits for folate determination, the best combination is given by $\mathrm{QM}$ and QCT. Table 11 shows that there is little to choose between the latter and other single kits in so far as cost, time, shelf-life, and subjective scoring are concerned. QM has some cost benefit over QCT but this factor will need consideration in relation to the performance of $\mathrm{QM}$ for $\mathrm{B}_{12}$ assay. For $\mathrm{B}_{12}$ estimation, QCT showed the best combination of analytical and clinical performance, the good analytical performance of AM being marred by the clinical findings. The analytical performance of QM was appreciably worse than for QCT, and we do not think that the cost and time advantages of
QM are justified in view of this; others may disagree on the priorities. NCM demonstrated appreciable cost advantages over kits but the analytical and clinical performance are less satisfactory. Direct comparison of the efficacy of the microbiological and the much more expensive radioisotope methods is difficult but the overriding consideration should be the analytical and clinical performance. For folate, the analytical performance in our hands is comparable with that of the best of the kits, and the clinical performance is acceptable. The decision which is preferable for an individual laboratory will depend on the workload, the equipment available, and previous experience with microbiological techniques. The $B_{12}$ microbiological method gave a satisfactory clinical performance, but unfortunately our testing programme did not permit a full analytical assessment. It seems unlikely on the basis of various quality control schemes (unpublished observations) that microbiological methods will be analytically better than the best of the kits. In our opinion, the case for preference of a microbiological method over an isotope method is less good for $\mathbf{B}_{12}$ than for folate, particularly when applied to laboratories with very different degrees of experience of microbiological techniques. It is well known that isotope methods are not affected by the presence of antibiotics, some of which interfere with microbiological methods. Patients known to be on antibiotics were excluded from our study, but no important discrepancies attributable to them were found in the few cases in whom later investigation revealed that such therapy had been given.

We are grateful to the Department of Microbiology, West Park Hospital, Macclesfield SK10 3BL, and especially to Lynn D Cameron for performing microbiological vitamin $\mathbf{B}_{12}$ assays.

Financial support for the investigation was provided by the Department of Health and Social Security. Copies of the full report may be obtained from Mr D Kennedy, Department of Health and Social Security, 14 Russell Square, London WC1B 5EP.

\section{References}

${ }^{1}$ Matthews D M, Gunasegaram R, Linnell J C. Results with radioisotopic assay of serum $B_{12}$ using serum binding agent. J Clin Pathol 1967;20:683-6.

${ }^{2}$ Davis R E, Nicol D J, Kelly A. An automated method for the measurement of folate activity. J Clin Pathol 1970;23:47-53.

${ }^{3}$ Johnson I, Guilford H, Rose M. Measurement of serum folate: experience with ${ }^{75} \mathrm{Se}$-selenofolate radioassay. J Clin Pathol 1977;30:645-8. 
${ }^{4}$ Waxman S, Schreiber C, Rose M et al. Measurement of serum folate by ${ }^{75}$ Se-selenofolate radioassay. Results of a multi-institutional clinical trial. Am J Clin Pathol 1978;70:359-63.

${ }^{5}$ Kubasik N P, Volosin M T, Sine H E. Comparison of commercial kits for radioimmunoassay: 111. radioassay of serum folate. Clin Chem 1975;21:1922-6.

${ }^{6} \mathrm{Hill}$ P W, Dawson D W. Evaluation of a commercial radioisotopic kit for folate assays. J Clin Pathol 1977; 30:449-53.

${ }^{7}$ Raven J L, Robson M B. Experience with a commercial kit for the radioisotopic assay of vitamin $B_{12}$ in serum: the Phadebas $\mathrm{B}_{12}$ test. J Clin Pathol 1974;27: 59-65.

${ }^{8}$ McGown E L, Lewis C M, Dong M H, Sauberlich H E. Results with commercial radioassay kits compared with microbiological assay of folate in serum and whole-blood. Clin Chem 1978;24:2186-91.

${ }^{9}$ Kolhouse J F, Kondo H, Allen N C, Podell E, Allen $R$ H. Cobalamin analogues are present in human plasma and can mask cobalamin deficiency because current radioisotope dilution assays are not specific for true cobalamin. New Engl J Med 1978;299:
785-92.

${ }^{10}$ Cooper B A, Whitehead V M. Evidence that some patients with pernicious anemia are not recognised by radiodilution assay for cobalamin in serum. New Engl J Med 1978;299:816-8.

${ }^{11 B r i t t ~ R ~ P, ~ B o l t o n ~ F ~ G, ~ C u l l ~ A ~ C, ~ S p r a y ~ G ~ H . ~ E x p e r i e n c e ~}$ with a simplified method of radio-isotopic assay of serum vitamin $\mathrm{B}_{12} . \mathrm{Br} J$ Haematol 1969;16: 457-64.

${ }^{12}$ Raven J L, Robson M B, Morgan J O, Hoffbrand A V. Comparison of three methods for measuring vitamin $\mathrm{B}_{12}$ in serum: radioisotopic, Euglena gracilis and Lactobacillus leichmannii. Br J Haematol 1972;22: 21-31.

${ }^{13}$ Wagstaff $M$, Broughton A. A simple routine radioisotopic method for the estimation of serum vitamin $\mathrm{B}_{12}$ using DEAE cellulose and human serum binding agent. Br J Haematol 1971;21:581-93.

Requests for reprints to: Dr DW Dawson, Department of Haematology, North Manchester General Hospital, Crumpsall, Manchester M8 6RB, UK. 